\title{
胃癌の細胞診に関する研究
}

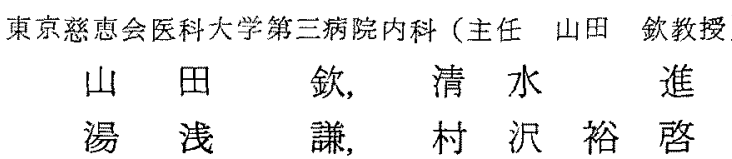

\section{STUDIES ON THE CYTOLOGIC DIAGNOSIS OF THE STOMACH-CANCER} BY

\author{
Shitō Yamada, Susumu Shimizu, Ken Yuasa and Hiroaki Murasawa \\ Department of Internal Medcine, Tokyo Jikeikai \\ University School of Medcine \\ (Prof.: S. Yamada)
}

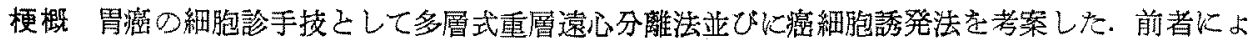

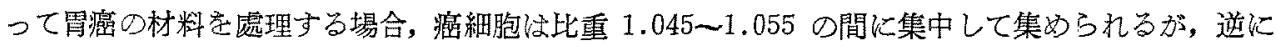

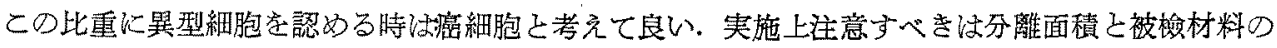

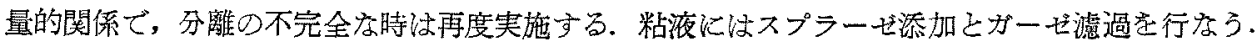

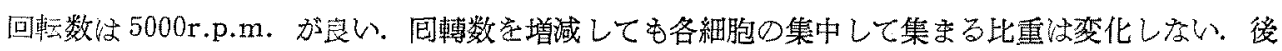
者はナイトロミン50〜100mgを静注し，6〜8時間後に吸引液乃至洗條液にて細胞診を実施方る. 34

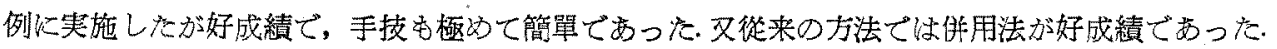

\section{I 緒 言}

細胞診は胃癌の優れた診断法であるが，臨林に おいてはその実施法に改良を必要とする点が少な く無い，特に簡單で有效な材料の採集法々採集し た材料の適切な処理法に成績改善の重要な鍵があ ると考えられる。

採集法として促来より奏掘されている方法は， 胃壁に麗出する病桼の面を直接擦過せんとする ものが多い，その為，操作が機械的で解剖学的関 係の複雑な生体器管には奏效しない悪もあり，㬰 施が繁染な上，伴なう苦痛も大である。処理法に 関しては往来の䂙究に㫊ど見るべき工夫が郍い。 しかも胃癌の材料には食物残湓, 血夜, 碉平上皮 等の夾雠物が多いので，少数の癌細胞では発見が 困難である。

我つは細胞診の新しい試みとして材料の採集法 には癌細胞誘発法を，処理法には多層式重層遠心
分離法を考案し，既に発表した如き好成續を得る 事が出来た。特に前者によつて方法の簡易化，苦 痛の軽減をみ, 後者によつて標本の制定家容易に すると共に結果を更に確実にする事が出来た。

その後, 漸次症例数も堌加し胃癌の成續として まと内る事が出来たのでこっに発表して関係各 位の御批制を仰ぎたいと思う。

\section{II 多層式重層遠心分離法亡 胃癌の細胞診に就いて}

細胞診は診断の稂拠を細胞個々の特微に求める 点が大きく, 癌細胞の特徴と云うも固有と断定し 得るものが殆どいため, 少数の, 特徽が不充分 な細胞のみでは明確な決定を下す事が出来ない。 又既に述べた如く，通過障害や機能不全のため食 物残渣が停滞し易く，出血もしばしば見る現象

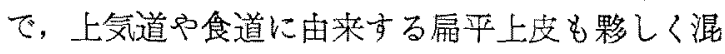
ずるのが常である。 
この様な材料から癌細胞のみを選択的に他の夾 雑物と分離して勧め，標本にする重が出来れば細 胞の判定に有利で，癌細胞が少数の場合も発見が 容易である，多㬝式重層遠心分離法はこの樣な目 的で,腹水の氿渣を連繶切片とするいわ的る cellblock 法の所見から生まれた考桇であるが，胃癌 に扔いても非常に好結果であつた。表 1 は従来の 單純に塗抹した標本と本法によつて材料を処理し た場合の標本について，検出した成績を比較した もので，明らかに本法が好成續を示している。

第1表。多層式重尿遠心分雜法の成績

\begin{tabular}{|c|c|c|}
\hline & 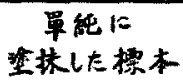 & 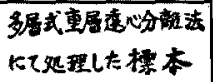 \\
\hline 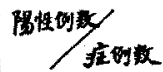 & $25 / 33$ & $32 / 33$ \\
\hline$\%$ & 75.7 & 96.9 \\
\hline
\end{tabular}

実施法に関しては溉に発表したのでこっでは省 略し，胃癌の材料における奏施要点と最近一部に 改良を加えているので，その概要を記述するに止 めたい。

A）分離面積について

良好な分離結果を得るためには予め知つていな ければならない点が二，三あり，分離面積と被检 材料の量の関係もその重要な一つである。嶈液や 吉田肉腫の細胞について材料中の細胞数を種々に 変えて，それそれに分離実験を行なうと，分離す べき細胞の総数が多過望る場合は分離の程度が不 完全である。最も適当な細胞数は分離面積 $1.5 \mathrm{~cm}^{2}$ (アラビアゴム溶液の境界面䅣，円柱状遠泌管な らばその槿断面積に当る)につき $3,000 / \mathrm{mm}^{3}$ 程 度の細胞数を有する被㭘液を $5 \mathrm{cc}$ 位使用する事で あつた。しかしながら胃癌の材料は食物残渣や粘 液等も分離すべき有珍成分の主要な量を占めるた め，分離結果の良否を論ずるには細胞の総数を規 定するだけでは不充分である。

沈椬の量は細胞数程正確ではないが，他に良好 なめやすがないので，沈渣の量と分離面積の関係
について最も良好な条件を追求してみた。ての結 果, 分離面積 $1.5 \mathrm{~cm}^{2}$ に坟しては1〜2 cc 程度 の量䘮使用するのが最良で，分離がよくなかつた 場合は再度分離操作を繰り返すと良好な標本を得 る事が出来る。

遠沈管の非は分離面積に関係する点が大きく重 要である、即ち管の下部が円錐状をなすものは円 錐部の分離面積が小で，使用に制限がある，50cc 用の太い管は分離面積汃大きいけれどを，分離さ れた細胞の吸引方不便である。我々は厚さ $1 \mathrm{~mm}$, 内徑 $1.4 \mathrm{~cm}$, 長さ $10 \mathrm{~cm}$ 管底迄円柱状をした遠沈 管を特製して使用している。

B) 粘液

粘液の存在はそのまつでは分離を阻害する。最 初は粘液を溶解する事によつて障害を除こうと考 え，酸，アルカリ，トリプシン等を使用したが良 好な結果は得られなかつた。

現在では粘液を生食水の均等な稀粉液とし，粘 性の強さを低下させる方法を採用している，刎論 そのま〉では均等な稀耜液とならない，スプラー ゼを加え $(2,000$ 單位 $/ \mathrm{cc}) ， 2$ 枚重ねた局方ガー ゼで濾過する方法を採つている。

C) 回転数

回転数の大小は遠心力の強さを決定する重要な 条件である．回転数を大きく的ると各細胞に㗢く 遠心力の差が堌大するので，比重の近似する細胞 を分離するには好都合である。しかし余り無制限 に大きくする事は細胞に惡影響を与えるため，嶈 夜における実験成績に基づき，従来の3,000r.p. m.を5,000r.p.m. に改めた。

表2 は色及な材料に㧍ける細胞の分離比重值を 比皎したもので，各細胞は比重の差が大きくなる 結果 3,000r.p.m. では分鱀する事の出来なかつ た細胞当 5,000r.p.m.の采用によつて完全に分 離し得る様になつた。しかし同種の組胞が集中し て集まる比重には㱠ど変化がない。これは細胞と 同時に媒質であるアラビアコム溶液にも同じ遠心 力が働いているからで，回転数を大きくした場合 に細胞を管底に向つて沈下させる力が増大する 
第 2 婊。回転数の相異儿上る分㒕状沇の比較

\begin{tabular}{|c|c|}
\hline 比重 & 各細胞 \\
\hline$\frac{1.030}{1.040}$ & $\begin{array}{l}\text { Fibrin，(自小校 } \\
\text { 粘洨，破片. }\end{array}$ \\
\hline $\begin{array}{l}1.040 \approx \\
1.045\end{array}$ & 扁平上皮 \\
\hline$\underset{1045}{1055}$ & $\begin{array}{l}\text { 胃腺上度 } \\
\text { 鹿境细胞 }\end{array}$ \\
\hline$\underset{1.050}{1.050}$ & 幻若りンバ球 \\
\hline$\stackrel{1.054}{\sim}$ & 细絧的胞 \\
\hline 1.076 & 中皮细胞 \\
\hline $\begin{array}{c}1.060 \\
1.075\end{array}$ & $\begin{array}{c}\text { クン八゚球 } \\
\text { 顆粒血球 } \\
\text { 肾上左 }\end{array}$ \\
\hline & 赤血球 \\
\hline 管成 & 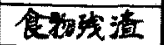 \\
\hline
\end{tabular}

$5.000 \mathrm{rrm}$.

\begin{tabular}{|c|c|}
\hline 比重 & 各細胞 \\
\hline 1.040 & 扁平上皮 \\
\hline$\frac{1.045}{1.055}$ & $\begin{array}{l}\text { 胃腺上皮 } \\
\text { 鷹埃細胞 }\end{array}$ \\
\hline $\begin{array}{r}1.050-2 \\
1.052\end{array}$ & 骨鹖苦芽球 \\
\hline $\begin{array}{r}0.054 \\
1.058 \\
\end{array}$ & 骨骴球 \\
\hline $\begin{array}{r}1.055-50 \\
1.060\end{array}$ & 㧅若ツン゙球 \\
\hline$\frac{1.060}{1.070}$ & 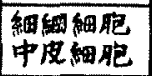 \\
\hline 1.0600 & リンパ球 \\
\hline $\begin{array}{l}1.066 \\
1.074\end{array}$ & 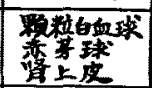 \\
\hline 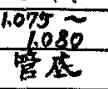 & 赤血球 \\
\hline
\end{tabular}

が，同時にアラビアゴム溶液の芫掛けの比重も增 大し，同じ比率をもつて細胞を静止させる力とな るからである。た だ型の細胞や比重の゙軽い細 胞，扁平な細胞等は粘性の影䛓を強く受けている ため多少分離の比重值は変化する。この事は換言 すれば，各細胞はそれぞれ独自の分離比重値をも ち回転数には無関㳢であると表現出来る。この他 分離が完結するのに必要な回転時間も短くて良い し，実施に当つて 3,000 r.p.m. の場合程熟練を 要しない等便利な点陊多い。

D) 癌細胞の比重

癌細胞は本法によってその大部分を比值 1.045 〜 1.055の間に集中的に集める事が出来る. 又こ の比重に異型細胞を認める場合は大体癌細胞と決 定して良い事が確かわられた。材料によつては变 性の強い癌細胞がこれより軽い比重にも少数見ら れるが，胃癌の材料ではかつる傾问が非常に少な ない，如何なる比重迄癌細胞が，ぞの様な割合で 分布するかを19例の胃癌から gastric balloon に て採集した材料について比重籍囲を追求したが， 上記の範囲を越えて少数の癌細胞分認められた症
例は僅かに 3 例であつた。彷つて胃癌の材料から 癌細胞のみを分離菟集する目的には比重 1.045〜 1.055の間を利用すべきで，我々は1.040，1.045， 1.055の三比量層を用い臨床における慣用比重と している．即ち癌細胞は 1.055 比重に集中して 集める事が出来, 食物残渣や血液, 細網系細胞等 は管底に、炶液の一部や扁平上皮等は 1.040 万至

1.045の比重に取り除々事が出来る.

癌細胞の分布する比重範围は材料によつて相当 の開きがあり，嶈液が最も広く（1.022１.060， 次いで喀留（1.040１.055)，胃の材料（1.045 〜 1.055) が最もせまい.同じ癌細胞でも材料の 種類によつて分布する比重範囲に相違のある事 は癌細胞の與味ある性質である。これは癌の種類 とは関係なく，癌細胞の制脱後の環境，即亏材料 の成分がそれぞれ異なつているため，癌細胞の変 性に相違を及ほしたものと考える事が出来る。胃 癌の場合が最もせまい点に関しては胃液の影響を 考えたわけであるが，检討の詳細はこ〉では筲略 する。

\section{III 胃癌の材料操集法の研究 (1)}

擦過法と洗浲法の併用法について

胃癌の材料採集法乙して報告されている從来の 万法は表 3 の如くで，これ等はその操作の性質か ら擦過を主とする方法と，洗淮を主とする方法に 大別する事が出来る，前者においては abrasive balloon が，後者に扔いては生食水洗涤法が最も 広く実施されている方法である。

理論的には abrasive balloon が最も確実に癌 細胞を啋集出来る筈である。しかしながら口腔， 咽頭，食道，胃を通過して病巣迄に至る経路は形

\section{第 3 表. 周癌の材料採取法}

1. 生食水洗湶法

2. Papain 法

3. Chymotrypsin 法

4. Abrasive balloon 法

5. Antral abrasive balloon 法

6. Gastric brush 法

7. Abrasive gastric nylon brush 法

8. Gastric biopsy 
態や機能が單純でなく，たぐの管ではない，從つ て時に正しく胃内を擦過出来ない事がある。加う るに摖過法は確実に病樂表面を擦過しない場合は 全く不成功に終る関係上，実施には相当な熟練々 概気分必要である。洗淮法法内胃内くまなく洗淮 するだけであるから，はるかに簡單で有効に違い ないが，癌細胞を剝脱する力が弱い．

結同擦過法も洗湺法もそれぞれ暴なつた長所と 欠点を持つているので，両者を併用して互いの欠 点を補う事が成續を改善出来る一つの方法であ る.balloonの表面から蛋き集めた材料と balloon の実施後に更に胃洗涤を行なつて得た洗滌液の雨 渚について成績を比較したが，表4の如く明らか に所用法の方が好成績であつた。この場合Cooper 然门指摘する通り標本には癌細胞以外の夾雑物呩 多く，時に良好な標本を得られない事もるるが， 我々は多層式重層遠心分離法も同時に箺施してい るため污染による不便は全く感じなかつた。

第 4 袁，僧用法実旅の成繢

\begin{tabular}{|c|c|c|c|}
\hline & 洗海液 & 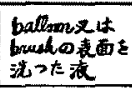 & 併用法空站 \\
\hline 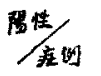 & $11 / 16$ & $14 / 19$ & $18 / 19$ \\
\hline 狯性 & $4 / 16$ & $5 / 19$ & $1 / 19$ \\
\hline
\end{tabular}

balloonのもう一つの大きな欠点は，浸潤によ り胃壁召硬化し狭窄の形を示す場合，殊に幽門㹨 窄の場合には，X線透視下で観察すると balloon が充分に膨化しないうちに噴閒部にもどつてしま い，充分に擦過出来ない事である。この様な埸合 には心缄カテーテルの尖端にスポンジを付けた brush を教案して使用し，好結果を得る事が出 来た。

\section{IV 胃癌の材料採集法の研究 (2) 癌細胞訮発法について}

胃癌は我が国における最も頻度の高い惡性蕾癔 で, 細胞診は單に胃癌と確定するだけの補助的手 段でなく，早期診断の可能な独立の臨床手技と考
えるべきである，従つて多くの疑いに過ぎない㱏 例も対象とするわけで，結果方確㬰であるのみな らず夹施も簡單で, 患者の苦痛や伦險, 病樂いの 壼影響等が軽度でなくてはならない。

あらゆる面加完全無欠の方法は無いかしい ないが，ある程度これ等の条件を霂足し得る万法 として良来の手技と全く異なる清想から, 患者に 徑癌剂，特にナイトロミンを投与する癌細胞訸発 法（又はナイトロミン誘発法とも云う）を考策し 郚㾁成績を求めてみた。

\section{A）実施方法}

架腹時にナイトロミン50〜100mg を静注し， 6 〜8時閒後に胃液を吸引して被検材料とする。通 過障害の無い場合は多孔性ゾンデにより，50〜 100ccのピストンで生食水を用いて坐位10回，卧 位10回の胃洗涤を行なうと結果は更に確実である (臥位は背臥位及び腹卧位の闭方).

\section{B) ナイトロミン総量とその副作用}

表 5 はナイトロミン誘発法を考案する動機と在 つた要点を挙げたものである．即ち組織は死後殂 化によつて脆くなり易剥脱性を堌すが，ナイトロ ミンを投与するとしぱしば出血性となり死後变化 と似た抢態变化や生活力の低下と共に同じ様に易 㓩脱性も增すので，二れを癌細胞の採集法に和用 せんと考えな。

ナイトロミンの技与によつて, 癌細胞が埰集し 易くなるか否かを追求するために，全体を明らか に触知し得る癌性睡瘤にナイトロミンを局所投与 して呀刺細胞診の経過を求め, 又肺癌の路痰や献 液についても追求し，陰性症例を陽性に転化出来

第 5 表。ナイト口ミン誘発法を考案した由来

1. 死後の組織は脆く, 易虽脱性である.

2. 死後の别脱細胞は生活機能なく, 形態も変化乙 ている。

3. 制癌剤投与に上る癌細胞は上記の死彷変化子似 ている。即ち, 形態が変化し, 生活機能は減退 を示す。

4.この他，制癌戍の投与はしばしば出血を来た し, 脆く, 陰性症例で癌細胞㔀脱を促す事が確 かめられた。 
る事砉定確かめているが，既に発表したので成續 の詳細は省略する。

癌細胞を䅎発する迄に必要なナイトロミンの総 量は，胃癌々腹水のふが50〜 100㫙上少量で充分 であつたのに対し，他の材料では 400〜 600mgの 投与が必要であつた。胃癌の場合はナイトロミン の投与によつて呕気仿来るので，相当強い不自然 な胃の逴動が薏起されるものと考えられる。促つ て癌細胞の剝離にはナイトロミンの制癌作用のみ でなく、この様な副作用も当然拹調して働いてい るものと若えられる．寿癌の場合に必要なナイト ロミン量が他の材料に比べて意外に少量でも良い のはこのためであろう。最近はこの副作用への考 筑から，高周波を癌局所に作用せしめて癌細胞を 得る研究に着手している。

C) 臨枺成續

現在迄にナイトロミン誘発法を実施した症例は 34 例で，表 6 注各採集法别に54例の症例における 成績を比較したものである，症例別の成續も実施 回数别の成績も共にナイトロミン誘発法が最も好 成續であつた。

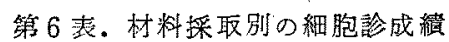
(置癌54例について)

\begin{tabular}{|c|c|c|c|}
\hline & 擦過法 & 洗港法 & 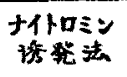 \\
\hline 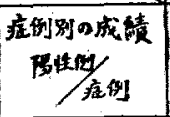 & $\begin{array}{r}17 / 20 \\
85.0 \% \\
\end{array}$ & $\begin{array}{l}14 / 22 \\
63.7 \%\end{array}$ & $\begin{array}{l}33 / 34 \\
99.6 \%\end{array}$ \\
\hline 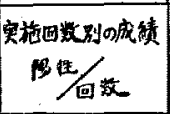 & $\begin{array}{l}17 / 24 \\
70.9 \%\end{array}$ & $\begin{array}{l}14 / 25 \\
56.0 \%\end{array}$ & $\begin{array}{l}33 / 36 \\
91.7 \%\end{array}$ \\
\hline
\end{tabular}

表 7 は各症例の成續を表示したが，第 1 例及び

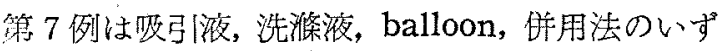
れも陰性で，誘発法によつて初めて陽性に枟化し 广症例で西る。特に第 1 例は洗洛法 balloon 併 用法を2 回実施するも陰性で，3回目柱偶然ナイ トロミンを投与した後に実施する結果となつたも のである．院性は第31例であるが 3 年前 balloon 法にて腺癌と沃定し切除した症例で, 再発後 2 回 実施したが陰性であつた。

表 8 は胃癌の部位や病型別に各材料の成績を比
第 7 表．各定例の成綪

\begin{tabular}{|c|c|c|c|}
\hline 10. & K8 & 畕化年 & f似代 \\
\hline 1 & & $\Leftrightarrow$ & $(t)$ \\
\hline 2. & & $(\rightarrow)$ & $(t)$ \\
\hline 3 & & $(+)$ & $(+)$ \\
\hline 4 & & $\Leftrightarrow$ & $(+)$ \\
\hline 5. & & $((1+))$ & $(t)$ \\
\hline 6. & & $(+)$ & $(t)$ \\
\hline 7 & & $\Leftrightarrow$ & $(t)$ \\
\hline 8. & & $(t)$ & $(-8)$ \\
\hline 9 & & $(-)$ & $(+)$ \\
\hline 10. & & $(1+4)$ & $(-f)$ \\
\hline III. & & $(+)$ & $(t)$ \\
\hline 12 & & $(t)$ & $(+)$ \\
\hline 13. & & $(t)$ & $(t)$ \\
\hline 13 & & & $(t)$ \\
\hline 15. & & & $(t)$ \\
\hline 16. & & $\Leftrightarrow$ & $(t)$ \\
\hline 17 & & & {$[(t)$} \\
\hline
\end{tabular}

\begin{tabular}{|c|c|c|}
\hline ro. & 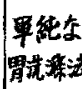 & 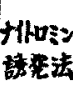 \\
\hline 18. & & $(t)$ \\
\hline 19 & & $(+)$ \\
\hline 20. & & $(t)$ \\
\hline 21 & & $(+)$ \\
\hline 22 & $(+)$ & $(+)$ \\
\hline 23. & $(-)$ & $(t)$ \\
\hline 24 & & $(t)$ \\
\hline 25. & $((++))$ & $(+)$ \\
\hline 26. & & $(t)$ \\
\hline $28 \%$ & $(t)$ & $(+)$ \\
\hline 28. & $(-)$ & $(t)$ \\
\hline 29. & & $(t)$ \\
\hline 30 & $\leftrightarrow$ & $(t)$ \\
\hline 31. & & $(\rightarrow)$ \\
\hline 32. & & $(+)$ \\
\hline 33. & & $(t)$ \\
\hline 34. & & $(t)$ \\
\hline
\end{tabular}

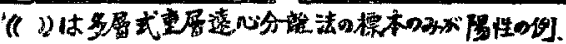

第8 关. 初回実施時の部位, 病型別の成綪

\begin{tabular}{|c|c|c|c|}
\hline & 擦遇法 & 洗棌法 & 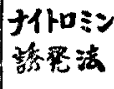 \\
\hline 硬性癌 & $1 / 2$ & $0 / 3$ & $2 / 2$ \\
\hline 些门湾 & $1 / 5$ & $4 / 6$ & $6 / 7$ \\
\hline 其の他 & $13 / 13$ & $5 / 7$ & $20 / 21$ \\
\hline \multirow[t]{2}{*}{ 合計 } & $14 / 20$ & $9 / 16$ & $28 / 30$ \\
\hline & $700 \%$ & $50.6 \%$ & $93.3 \%$ \\
\hline
\end{tabular}

浶した，従来の方法仕胃癌の発生した部位や病型 によつて成績に相違が認められ，幽門癌や硬性癌 に於计る成績が不良であるが，誘発法ては，これ らに全々無関係の良好な成續であつた。特に幽門 部の罢癌は臨床上しばしば遭遇する早期胃癌の部 立で，この成結が惡いとすれば細胞診が最も注目

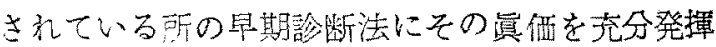
出来るとは言えないと思う。我々のナイトロミン 
策 9 表。時街心比㕮

\begin{tabular}{|c|c|c|}
\hline 项目 & $\begin{array}{c}\text { gastric balleson } \\
\text { 法 }\end{array}$ & 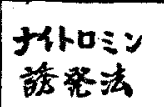 \\
\hline 钿胞の形態 & 新解。 & 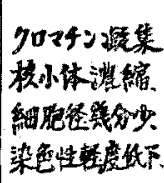 \\
\hline 病型 & 幽门部性不道 & $\begin{array}{l}\text { 凡中る病型に } \\
\text { 道する。 }\end{array}$ \\
\hline 病菓刺戟 & 1 & $\begin{array}{l}\text { 治素の意味 } \\
\text { もある }\end{array}$ \\
\hline 手技 & 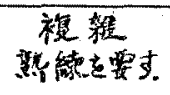 & 简缶 \\
\hline 虽者の苦痛 & , & 軽度 \\
\hline
\end{tabular}

秀発法はこの点に関しても充分満足し得る成續で あつた，又彷来の方法はさきに述べた如く病型に よつて方法を筫択する必要もあつたが，我々の才 法では全くその必要を認めなかつた。

表 9 は证来の手技のうち比撆的成績が良好々言 われる abrasive balloon とナイトロミン誘発涪 の特徵を比較したもので,ナイトロミン誘発法は 操作の簡單な事, 患者の苦痛や仵險のすくない 事, 胃癌の発生した部位や病型が結果に影響する 点の少ない事, 病笨に㤠影響のみられない等の膺 れた特徵が見られる。

\section{$\mathbf{V}$ 考 案}

細胞診の成續を改善する目的で多層式重層遠心 分離法並じに癌細胞誘発法考省案し，特に胃癌に

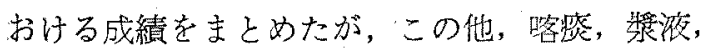
驾刺等にも実施して非常に好成續であつた。又多 層式重層遠心分離法は癌の色々な材料だけに上立 らず白血病においてもその診断に役立てる事が出 来た。即方細胞診においては材料中の癌細胞のみ を選択的に多数, 比重 $1.045 \sim 1.055$ の間に集內 る事を得，同時にその際の比重によつて細胞を牱 定する，新しい基準をもうける事功出来たが，白 血病に予いても診断を確定出来る幼若球のみを集 中的に集め，その比重によつて細胞の由来を決定 する事が出来た（表 2 ). な招血液疾患の猃断に関
しては别の機会に発表する。

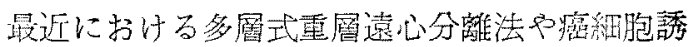
発法の色々な材料における成績をあげてみると， 前者では槳腹が50/51・98.0\%，喀痰では16/18・

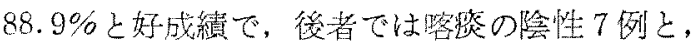
穿刺細胞䪭陰性の7例を，おのおの6例うっ陽性 に标化出来な。

我々の力法は勿詇未だ完譬と言えるものではな く，令後更に研筑在重放る予定であるが，細胞診 の様な磪夷さを癌の集団积診，特に胃癌にとりい れたいと考え，そのためには徒来の如く方洷が繁 集であつたり患者に苦痛を与えるものは適当でな いので，その簡易化と云う意味で癌細胞誘発法を 考笔した。文多層式重層遠心分離法は細胞の制定 に新しい基集をもうける目的で最初から比重に注 目して研究を進めたもので，一灾成功したと考え ている。

\section{$\nabla$ 結 論}

胃癌の細胞骖における手续として, 多層式重層 遠心分離法, 癌細胞誘発法を考案したので寒施要 点已臨床成續を報告した。

前者によつて癌細胞は比重 $1.045 〜 1.055$ の間 に集り，及この比重域に異型細胞を認める時は癌 細胞已考えて良い事を確かめた。後者は良来の繁 雑で, 㭧者の苦痛の大きい方法に代り得る優れた 検出成績が得られた。灭侹来の方法についても擦 過法と洗淮法の做用法が最导好成續であった。

\section{参考文献}

1) 黑川利踥他：猃断飞治撚，45，(2)，95，昭32. $-2)$ 綾部正大: 霄癌の細胞学的猃断, 1957, - 太田邦夫：內科の領域，4 (12)，703 712, 昭31. -4) 山田剑: 范医誌, $74(12), 2751 \sim 2770$, 昭

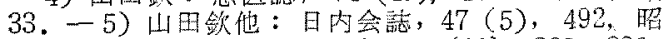
33. - - 6) 山田欽也：日消誌，55(11)，838，839, 骂33. - 7) 山田釷他: 日消誌, $56(11,12), 1095$, 昭34. - -8) 清水進: 日消誌, 55 (11), 795 807,

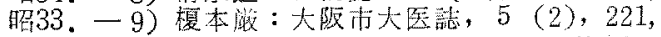
昭31. - 10) Papanicolaou: Atlas of Exfoliative Cytology, 1954. - 11) Graham: Cytologic Diagnosis of Cancer, 1950. - 12) Nieburg: Cytologic Technics, 1956. - 13) Osborn: Applied Cytology, 1953. -14) Spriggs: Cytology of Effusions, 1957. -15) Agranoff: Blood 9, 804, 1954. -16) Spear: Blood, 3, 1055, 1948. -17) Vallee et al.: Science, $3,34,1950,-18$ ) Cooper and Papanicolaou: J.A.M.A., 151, $10 \sim 14$, 1953. -19) Panico et al.: J.A.M.A., 143, 1308, 1950. - 20) Ayze and Oren: Cancer., 6, 1177 , 1953. 